TAPROBANICA, ISSN 1800-427X. April, 2010. Vol. 02, No. 01: pp. 30-47.

(C) Taprobanica Nature Conservation Society, 146, Kendalanda, Homagama, Sri Lanka.

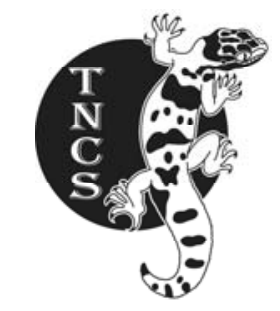

\title{
THE EFFECTS OF CLIMATE CHANGE ON GLOBAL WILDLIFE AND TERRESTRIAL ECOSYSTEMS
}

Thilina Surasinghe

Department of Forestry and Natural Resources, Clemson University, Clemson SC, USA
E-mail: tsurasi@clemson.edu

\begin{abstract}
Climate change and biodiversity are interconnected, where climate change is reshaping global biodiversity. Unsustainable human activities that increase accumulation of greenhouse gases and hinder the natural balance of atmospheric greenhouse gases aggravate the effects of climate change on biodiversity. Rising seas-levels could inundate coastal habitats and stem the flow of nutrients from the ocean to the terrestrial ecosystems. Altered climate regimes directly affect wildlife, their behavior, migration, foraging, growth and reproduction. Climate change could disturb the dynamic equilibrium of terrestrial ecosystems by affecting ecosystem productivity, biomass production, hydrological balance, and trophic interactions. Further, climate change intensifies natural disasters and shifts in natural disturbance regimes. Such processes impose physiological and environmental stress on terrestrial ecosystems which adversely affect the ecosystem resistance and resilience. Moreover, warming atmosphere causes thermal optima to shift towards high latitudes and high altitudes. Terrestrial biota readily responds to temperature, where both flora and fauna alter distributions toward more favorable climatic conditions. Some climatic parameters that drive life history events, such as photoperiod, are fixed, while others, such as the timing of spring weather, are changing because of greenhouse gasses. The resulting mismatch between fixed and variable drivers of phenology, such as in mating, breeding, migration, hibernation, and post-hibernation activities, will disadvantage some species and benefit others. This will result in new ecosystems. Warming temperature favors biological activities of wildlife pathogens, since high temperature increases breeding rate, survival, hatching success and transmission of wildlife parasites and disease-causing agents. Climate change dissociates species interactions, mutual associations and a multitude of ecosystem functions. Ultimately, climate change predisposes native terrestrial wildlife to extinction and alters the functions and structure of terrestrial ecosystems. Biodiversity provides ecosystem services including the regulation and mitigation of the adverse impacts of climate change. Therefore, biodiversity conservation and terrestrial ecosystem management is critical to address climate change. Robust climate-oriented models with the use of GIS and remote sensing technology are needed to make effective predictions about the spatial and temporal effects of climate change.
\end{abstract}

Key words: Global warming, Biodiversity, phenological changes, Range shifting, Wildlife diseases 


\section{Introduction}

Environmentally unsustainable anthropogenic activities have resulted in a significant increase in the atmospheric concentrations of greenhouse gases has substantially increased the global average ambient and sea surface temperature. This situation has convoked changes in the natural climatic regimes in the global scale. Climate change has impacted natural terrestrial ecosystems and wildlife in multiple ways. Dramatic shifts in physical atmospheric conditions, climate events, and natural disasters; shifts in geo-climatic regimes in different biomes of the earth; invasion by exotic species and high prevalence of wildlife disease are a few results of climate change that have already been observed. Sea level rise is likely to occur during this century, with serious impacts to island and coastal ecosystems. Consequently, many species have lost some of their native habitats, geo-climatic associations and physiologically optimal environmental conditions. Therefore, many species have undergone reduction of their geographical range and become highly vulnerable to extinction. Further, few species moved towards either high latitudes or high altitudes in response to climate change but other species failed to reestablish their habitat associations, and phenological responses differ among different species in the same ecosystem, ultimately causing disintegration of ecosystem components. Thence, climate change should be considered as a key factor responsible for biodiversity loss and natural ecosystem degradation. Future conservation plans should include management actions to mitigate adverse impacts of climate change.

Nearly all of the biological activities of Earth strictly depend upon solar energy. Solar energy supports primary producers, sustaining majority of the biomass on the planet. Further, solar energy is the heat source that keeps the plant earth under biologically tolerable levels. $\mathrm{CO}_{2}$ plays a vital role in trapping solar radiation within the earth's atmosphere to elevate atmospheric temperature, phenomenon is known as the greenhouse effect (Abrahamson, 1989), where several natural and anthropogenic gases trap infra-red radiation and subsequently elevate atmospheric temperature. Apart from $\mathrm{CO}_{2}$, gases like $\mathrm{CH}_{4}$, (methane) $\mathrm{CFC}$ (chlorofluorcarbons), water vapor, $\mathrm{N}_{2} \mathrm{O}$ (nitrous oxide), $\mathrm{SF}^{6}$ (sulfur hexafluoride), $\mathrm{HFC}$ (hydrofluorocarbon) and $\mathrm{O}_{3}$ (ozone) are responsible for the greenhouse effect (Barnett, 1991).
The greenhouse effect; is a natural phenomenon, but is anthropogenically enhanced. The natural greenhouse effect is essential for existence of life on earth, without it the average global temperature would be $-18^{0} \mathrm{C}$, a thermal point that is far below biological sustainability (Abrahamson, 1989). However, several adverse anthropogenic activities increase the atmospheric concentrations of greenhouse gases, aggravating the natural greenhouse effect, and leading to the enhanced greenhouse effect aka global warming. This condition increases the global atmospheric and sea surface temperature, which is sufficient to cause devastating climatic changes and environmental catastrophes (Appenzeller, 1992). During the $20^{\text {th }}$ century, the average global sea surface temperature has risen by $0.78 \pm 0.18^{\circ} \mathrm{C}$, a trend which intensified particularly within the last couple of decade (IPCC, 2007a). Since 1978, sea surface temperature has risen exponentially, and 2000-2009 period has being the warmest decade since then (IPCC, 2007b). According to the climate model projections of the Intergovernmental Panel of Climate Change, the average sea surface temperature will continue to rise further 1.1 to $6.4{ }^{\circ} \mathrm{C}$ by the turn of the twenty-first century. Drastic, temperature-driven climate changes, such as unusually hot winters and springs, alterations in precipitation, changes altered timing in seasonality, intensified natural disasters such as wildfire, hurricanes, floods, and droughts are globally blatant indications of global warming and climate change, which can impose gravid impingements on natural ecosystems and wildlife (Barry, 19; Brewer \& Franklin, 2000). The ability of ecosystems and their occupants to adapt to climate change depends critically on the rate of change. Given to the fact that the temperature-rise in the past $20 \mathrm{yrs}$ is 8 times that of the last $100 \mathrm{yrs}$, the rate of climate change is too rapid for most species to adapt (IPCC, 1992).

\section{Sea level rise}

For the past 100 years, sea level has risen by $10-25$ $\mathrm{cm}$, and it is predicted that this figure will shoot further up with increasing sea-surface-temperature. Two physical drive sea level rises as consequences of global warming. As atmospheric temperature rises, sea surface that is in equilibrium with the atmosphere will increase in temperature leading to thermal expansion of seawater. Additionally, the warming atmosphere will cause glacial ice sheets and snow cover on land to melt, adding more water to the ocean (IPCC, 2001). Coastal ecosystems will suffer greatly from sea level rise. Inundation of inland coastal habitats will result habitat loss, 
particularly for estuarine, beach and sand dune communities. The loss of deltas and estuaries will be especially acute because of their productivity and the diversity of biological communities that they support and on which many human communities depend (Ericson, 2006). Sea level rise has been the causative agent for decreased diversity and declines in population sizes of coastal intertidal invertebrates (Barry et al., 1995). Sea level fluctuations can imperil the survival of species inhabiting low-lying islands. The Key deer (Odocoileus virginianus clavium) in Florida Key islands (Lovejoy, 2008) is but one example of many island endemics whose habitats will be inundated by sea-level rise. The coastal wetland habitats and tidal influx serve as a pathway for inland movement of marine derived nutrients, which later supports the terrestrial biota. Rising sea level will not only stem such nutrient introduction processes but also exert a physical stress on coastal communities, culminating in lowered productivity and diversity in coastal ecosystems (Titus, 1988). A coastal ecosystem especially susceptible to sea level rise is mangrove forests (Alongi, 2008; Ericson, 2006; Field, 1995; Pernetta, 1992). These productive and diverse ecosystems, adapted to shallow, brackish water, occur throughout south Asia, the Pacific Islands, tropical-Atlantic South America and the Caribbean (Ali 1996; Pernetta, 1993). For example, in the Pacific islands, the total mangrove area is about 343,735 ha, with largest areas in Papua New Guinea, Solomon Islands, Fiji and New Caledonia (Ellison, 2003). They also occupy large areas where tidal effects reach far inland in some states, such as Bangladesh, Brazil and Cambodia. Loss of these habitats would be devastating to fishing communities and a major assault on biodiversity.

Sea level rise will aggravate coastal erosion which reduces space available for coastal communities. Regression of coastal vegetation can also happen due to insufficient landward sedimentation influx, which is a result of sea water inundation. Due to frequent submersion, climax communities in costal vegetation may reverse back to primary colonizers. Hence the sequence of plant communities will be repeated, and in each cycle the recovery will be slower than the first (Houghton, 2001).

\section{Altered precipitation and other natural climate regimes}

Unusually warm atmosphere causes warm, moisture-rich air to penetrate further north than normal, which transports more moisture to high latitudes from mid and lower latitudes resulting in high precipitation at high latitudes, and droughts in mid and low latitudes (IPCC, 2007a). This is a severe threat to tropical ecosystems, which are adapted to high moisture regimes. Such climatic extremities drastically reduce resource availability, especially water and food. Prolonged droughts result in major vegetational changes converting forests into grasslands and scrublands (Neelin et al., 2003). Natural vegetation responds rapidly to abrupt changes in precipitation. In New Mexico, the distribution extents of Ponderosa pine forests and Pinon juniper woodlands decreased substantially in response to a prolonged regional drought (Allen \& Breshears, 1998). Further, increased precipitation, in form of snow and ice can significantly reduce foraging efficiency of browsing and grazing ungulates and predisposing them for predation. Increased snow depth in Isle Royale lead to decreased foraging efficiency in moose and increased predation by gray wolves (Gese \& Grothe, 1995). Further, Woodward \& Rochefort (1991) predicted that $3^{\circ} \mathrm{C}$ rise in temperature and $10 \%$ increment in precipitation will decrease the number of plant families, with Eastern Australia getting most deleterious reduction in floral diversity. Further, Kirschbaum \& Cen (1999) prefigured 50\% decline in biomass growth, accompanied by declined primary productivity in the Northern Australia under $20 \%$ declination in rainfall. Hilbert et al. (2001) estimated that that the extent of highland rainforests of Northern Queensland of Australia will shrink by $50 \%$ with $10 \%$ reduction of rainfall under warming trends. Highland rainforests of Northern Queensland is a local hotspot for numerous endemic vertebrates whom will disappear with the loss of rainforests (Hibert et al., 2004). Global warming does not universally decrease precipitation. Abnormally high precipitation has recorded in certain areas, which has modified the regional vegetation structure drastically. This is known as vegetation thickening, where the abundance of woody vegetation increases considerably in low-density vegetation biomes such as semiarid woodlands, sparse scrublands, and grasslands (Hilbert \& Ostendorf, 2001). This alters the gross habitat structure as well as microhabitat features of a given biome which might render the "thickened" habitat unsuitable for native species that prefer relatively open, sparsely vegetated habitats (Berry \& Roderick, 2002). Similarly, expansion of rainforests into grasslands of Southeast and Northern Queensland in Australia has been attributed to more-than-average rainfall (Hughes, 2003). 
Regional climate plays an essential role in shaping habitat structure and governing habitat selection of wildlife. Therefore, changing climate could modify historical distribution ranges of species, where ecological invaders expand their range, replacing other species in response to changing climate. In the boreal region, warming climate promoted northward expansion of Red foxes outcompeting Arctic foxes (Hersteinsson \& MacDonald, 1992). Global warming increases the magnitude and the frequency of extreme climate events, such as droughts, wildfire, hurricanes, storms, and periodic climate shifts such as Northern Atlantic oscillation and Elnino Southern Oscillation (Chavez et al., 1999). Drastic alterations of natural climate regimes convoke irreversible species responses that jeopardize their life cycle. For instance, prolonged droughts enhance evapotranspiration leading to low moisture availability and extreme dryness which are detrimental for many species. Further, prolonged droughts in arid ecosystems will increase the frequency and the intensity of wildfire (Peters, 1998).

\section{Effects on natural vegetation and changes in vegetation zones}

There are multiple effects of climate change that potentially influence natural vegetation structure and function. Simply, climate change modifies seasonality, the frequency and the intensity of heat waves, and cold fronts, alter natural precipitation regimes, soil moisture regimes, relative humidity, and ambient temperature (Knapp et al., 2008). All these facts govern growth and propagation of natural, native vegetation. These physical elements particularly affect the nutrient availability for plants, biochemical reactions (particularly photosynthesis and respiration), physiological stress, nutrient and carbon assimilation (McGuire et al., 1993).

Poleward movement of plants has been widely documented and parsimoniously correlated to climate change in the alpine areas. In the recent past, there has been a significant trend on establishment of trees in subalpine and treeline stands. Further, native vegetation have colonized multiple regions beyond the current treeline, both in terms of latitude and altitude (Dullinger et al., 2004). For example, in European Alps, plant species richness on 30 peaks has increased by $70 \%$, presumably because of upward colonization (Hughes, 2000). Grabherr et al. (1994) discovered that plant communities in Swiss Alps shifted their distribution range within 40-90 years in response to increased ambient temperature. In response to increasing temperature, modifications can occur in vegetation cover and vegetation types. Boreal and temporal forests are the most sensitive vegetation biomes for warming effect (Ulrich, 1990). Hence, if the current warming trend keeps going, percentage cover of temperate forests, boreal forests and tundra forest are expected to decline significantly. Tropical and subtropical forests will also decline to greater extent. The total land area covered by grasslands and deserts will increase (Ozerda \& Boreal, 1990). Atmospheric warming has resulted massive forest diebacks in montane forests in Costa Rica where changing climate accompanied diebacks in many endemic cloud forest flora (Still et al., 1999). Boreal forests and temperate forests will be replaced by cool temperate steppe, and to a lesser extent, by boreal and temperate dry scrublands. Subsequently the mid and low latitude vegetation will be reduced greatly. Theoretically, a $1{ }^{\circ} \mathrm{C}$ rise could cause vegetation zones to shift about $200 \mathrm{~km}$ towards poles (Emanuel, 1985). Altitudinal changes in vegetation zones can also be significant. With a $3{ }^{0} \mathrm{C}$ rise, vegetation belts will move about $500 \mathrm{~m}$ upwards (Emmanuel, 1985). Consequences of this would be elimination of some species from certain geographical regions.

\section{Changes in the geographical range of fauna}

The geographical distribution of wildlife is highly influenced by climatic regimes, often by the means of species-specific physiological thresholds of temperature, precipitation, ambient humidity, and moisture regimes (Hoffman \& Parsons, 1997). With on-going warming trends, these 'bioclimate envelopes' move towards poles or higher altitudes. Moreover, Habitat occupancy of fauna can be highly influenced by presence of their preferred vegetation community, which could shift in response to climate change. Therefore, within the limits of their dispersal capacity and resource wild fauna will track shifting climatic envelopes as well as their preferred vegetation community and shift their range poleward in latitude and upward in altitude (Pearson \& Dowson, 2003). When temperature changes along latitudes, species move to higher latitudes in search of their preferred climate regimes, particularly in search of the optimal thermal range because their original habitats are too warm for them. Long-term observations have revealed that shifting climate inevitably shifts geographical range of many taxa, particularly on birds, mammals and butterflies (Hill et al., 1998; 1999; Beever et al., 2003). The range-shift phenomenon is pronounced in all the biomes of the planet and are mostly recorded in Arctic, Antarctic 
and temperate biomes. Density and abundance of species may change at given locations and the ranges of species may shift either poleward or to higher altitudes as species move to occupy areas with tolerable temperatures that are in accord with their metabolism (Berteaux et al., 2004; Blenckner \& Hillebrand, 2002; Both et al., 2004).

In North America and Europe, birds and butterflies have migrated northward with warming climate for the past 50 years (Parmesan et al., 2000; Thomas \& Lennon, 1999). For example, 59 species of residential breeders in Great Britain and two third of European non-migratory butterfly species have shifted their range northward with warming climate (Parmesan, 2006). Northward movement of butterflies has been documented linking the migration to positive temperature anomalies in spring and summer (Hughes, 2000). Besides, several Mediterranean and African dragonflies have been recorded in increasing abundances in Europe, while the native European insects contracted their ranges with increasing temperature. In the United Kingdom, 23 of 24 residential Odonata species shifted their range northward by $88 \mathrm{Km}$ during the 1960-1995 period, concerting with increased atmospheric temperature. Range shift is evident in tropical regions as well (Ott, 2001). The Rufous hummingbird showed a dramatic change in its' winter range within a decade's timeframe. This species' winter range historically did not transcend Mexico. For the period from 1900-1990, there were only a low number of sight records on Rufous hummingbird during the winter season. Interestingly, from 1990 to 1996, winter sight records increased strikingly, and by 1998 winter, a residential breeding population was recorded 400 $\mathrm{Km}$ inland. This range shift corresponded to a $1^{\circ} \mathrm{C}$ rise of the regional temperature (Hill et al., 1998; Howell, 2002).

Range shifting in response to climate change along latitudinal gradients is reconstructed along elevation gradients too. Naturally, with every $160 \mathrm{~m}$ elevation, temperature goes up in $1{ }^{\circ} \mathrm{C}$. Therefore, the thermal gradient along montane habitats is more pronounced. It has been recorded that warming atmospheric temperature drives species to move from lower altitudes to higher altitudes in search of suitable climate conditions. In a multi-taxon study involving both vertebrates and invertebrates with different habitat associations, Hickling et al. (2005) showed that 83 percent of focal species shifted northward whereas 50 percent moved to higher altitudes. An avifaunal survey along an altitudinal gradient in the Monteverde National Park, Costa Rica, revealed that lowland birds breeding and nesting in montane areas, following a warming trend in a 20-year period (Pounds et al., 1999; 2005). Based on a study in Central Spain, Wilson et al. (2005) recorded upward shift in the lower altitude limit of 16 species of butterflies by $212 \mathrm{~m}$ within a 30-year period, which was driven by a $1.3^{\circ} \mathrm{C}$ rise in average annual temperature. This range shift resulted a one-third reduction of the butterflies' original area of occupancy.

There are several ecological constraints encountered by species when shifting ranges along latitudinal and elevation gradients (Grabherr et al., 1994). Although species from lower/mid latitudes and lower/mid elevations can move to higher altitudes and higher latitudes, species occupying higher latitudes and higher elevations do not have any physical space to shift. Thence, their geographical range will be constricted due to poleward expansion of species that previously occupied lower latitudes or altitudes. For example, the American pika (Ochotona princeps), a common Lagomorph that is distributed in Western North America as isolated populations on multiple montane peaks, has no alternative habitat to migrate in the face of climate change (Lovejoy, 2008). Not all species can shift their range with equal efficiency against changing climate. Moreover, not all the populations of a species are capable of moving poleward or towards higher elevation because of dispersal limitation, physiological incapacity to migrate, or simply due to absence of alternative suitable habitats (Hannah et al., 2002). Therefore, species that are unable to shift their range rapidly will perish. This predicament is particularly true for populations of species that occupy lower limits in latitude and altitude. Populations of a given species that occupy lower latitudes and low elevations have to transverse the greatest distance to reestablish their bioclimatic associations, and they probably need to migrate through land use types that are unfavorable for them (Dale et al., 2001). Among European and North American butterflies, subpopulations that resided lowlands and southernmost habitats have undergone local extinction with climate change (Parmesan et al., 1999). Local extinctions yield adverse impacts on metapopulation dynamics and genetic heterozygosity of a species. Besides, for the species to shift there should be continuity of preferred habitats along the landscape. Unfortunately, this may not be a reality in face anthropogenic land uses where habitats are fragmented, disrupting the continuity (Dale et al., 
2001). Nonetheless, naïve biogeographical regions colonized by shifting species may not suite them for long-term survival or to establish a continuously reproducing population. For example, the Desert Orange-tip (Colotis evagore), a native butterfly to the northern Africa colonized Southern Spain, following the warming trend. In their new range, the butterfly retained its host specificity to Caparis spinosa, its' larval host plant, while showing preference to a hot microclimates. Physiological studies showed that they require a temperature greater than $12^{\circ} \mathrm{C}$ continuously for 162.5 days for larval development. Nevertheless, the winter season of southern Spain is favorable for their neither larval host plant nor larval maturation. Since the butterfly has not find an alternative larval host plant or not evolved a winter diapause stage, the future survival of this species is highly ambiguous (Jordano et al., 1991).

Shifting range in face of climate change is not an option for habitat specialists. Species that require unique environmental conditions and microhabitat characteristics are called habitat specialists. Therefore, with climate change, the extent habitats suitable for such specialists will dwindle. Stringent life history strategies will prevent them from adapting to a different habitat migrating to higher elevations or upper latitudes is not an option for them. In Northern Britain, 89 percent of habitat specialist-butterfly species have undergone population shrinkage in face of $1-1.5^{\circ} \mathrm{C}$ increase in the summer-spring temperature within 25-year period (Warren et al., 2001). Endangered species confront a similar fate under global climate change. Most often, habitat specialists are considered endangered or threatened due to their intrinsic nature. Brereton et al. (1995) estimated that of 42 threatened vertebrates of Southeast Australia, 41 will suffer from significant range restrictions and 15 species would suffer from complete loss of their preferred habitats with $3^{\circ} \mathrm{C}$ elevation in temperature. Even species that currently have broad geographical range might be adversely affected by climate change as well. Cosmopolitan distribution does not necessarily suggest that those species are highly adaptable or they have a wide bio-climatic tolerance. Certain species might be broad in distribution regime, simply because there are ample habitats that fall within their physiological and environmental preferences. However, if they have a very limited thermal tolerance, climate change will deter them from their previously suitable habitats. Therefore, high abundance or wide distribution of species does not imply that they are resistant to climate change. Through bioclimatic modeling, Beaumont and Hughes (2002) estimated that if temperature increases by $0.8-1.4^{\circ} \mathrm{C}$ by the turn of the year $2050,88 \%$ of Australian butterfly species that naturally had an extensive distribution would decrease in their original area of occupancy. Wilson et al. (2005) compared distribution records of broad-ranging butterflies for 35 years in Sierra de Guadarrama mountain range, Central Spain, and discovered that 16 montane butterfly species shifted their distribution range towards the mountain top by moving $212 \mathrm{~m}$ uphill, which caused them to contract a third of their original distribution extent. This range shift corresponded to $1.3^{\circ} \mathrm{C}$ increment in temperature within the same 35 years and $225 \mathrm{~m}$ shift in isotherms along this mountain range.

\section{Impacts on species traits}

One of the key impacts of climate change on species traits is phenological alterations. Modifications in phenology include marked changes in species life history events such as initiation of breeding season, singing period, arrival dates of migrant birds, emergence dates of winged insects, dates of first amphibian choruses, first spawning dates of amphibians, sprouting and flowering seasons of plants, lengthening of growing season of plants, period for fall coloration of leaves, hibernating dates and dates for waking-up from hibernation (Walther et al., 2002). Many phonological studies carried out globally, particularly in North America and Europe provide credence for significant degree of phenological alterations, most of which indicated advanced life history activities that coincide with either elevated temperatures or altered precipitation. For instance, Crick et al. (1997) observed that 75\% of 65 European bird species showed a nine-day advancement of spring breeding observed on breeding biology during 1971-1997 study period. Egg lying days of Canada Geese and Arctic Geese of Canadian Arctic have advanced by 30 days within (1951-1986) three decades (MacInnes et al., 1990). Menzel et al. (2006) used an extensive phenological network (1971-2000) to conduct a meta-analysis on 542 floral and 19 faunal species in 21 European countries where they discovered that $78 \%$ of all leafing, flowering and fruiting records have advanced significantly. Besides, in several occasions, flowering and defoliation of native flora have occurred considerably earlier than usual. For example, the average flowering dates of Lilac (Syringa vulgaris) and Honeysuckles (Lonicera tatarica and L. korolkowii) in the western United States have advanced by 2 and 3.8 days per decade, respectively (Cayan et al., 2001). Among pond 
breeding anurans and newts, the breeding, mating and spawning periods have advanced significantly (Beebee, 1995). Gibbs \& Breisch (2001) compared two sets of records (historical records 1900-1912 and recent records 1990-1999) on amphibian vocalization within a 100 -year time duration for six frog species in Ithaca, New York, and noted an advancement of 10-13 days associated with a 1.0 $2.3^{\circ} \mathrm{C}$ rise in temperature. In England, amphibian breeding dates have advanced by 1-3 weeks per decade which were linked to changes in night time and daytime temperatures (Beebee, 1995).

Warming climate affects migration phenology as well. For example, in North America, over a 90year-period, among 76 migratory bird species, 39 species arrived earlier in the spring. Conversely, among European passerines, the fall migration was delayed significantly with warming climates. It is believed that changes in temperature and precipitation are the responsible factors that have driven these phonological changes (Parmesan \& Yohe, 2003). Seventy percent of butterflies in central California showed an average of 24-day advancement in their first flight dates within a 31year period, attributed to warmer, drier winters (Forister \& Shapiro, 2003). In contrast, Gordo et al. (2005) found that three of six long-distance migrant bird species have significantly delayed arrival to breeding grounds in Spain, with arrival date highly correlated with climatic conditions in their overwintering grounds in the southern Sahara. A marked change in the winter distribution of birds in the Cape Cod, northeastern United States was noted based on the Christmas Bird Count from 1930-1990 concerted with increased in local mean minimum winter temperature. During this period, more birds that used to have a southern winter distribution overwintered in the Cape Cod. This suggest that local amelioration of winter temperature and global temperature abnormalities have induced a discernible shift in the distribution of winter avifauna in Cape Cod, with southern species appearing more frequently and presumably northern species moving further north. Alteration of natural habitat structure of Cape Cod during the above timeframe itself is not sufficiently large to explain the changed composition of the overwintering avifauna (Valiela \& Bowen, 2003).

Modification of behavior, morphology and physiology in response to changing environmental conditions, especially those that deals with timing of biological activities with respect to seasonal events, is known as phenotypic plasticity (Bradshaw \&
Holzapfel, 2006). However, in multiple instances, it has been shown that heritable genetic alterations have resulted in populations of diverse taxa, where it is hypothesized that climate change acts as a selection pressure. For example, early appearance of spring resulted advancement of Spruce cone peak production in Canada. Interestingly, Canadian Red Squirrels started mating earlier than usual to capitalize on maximum production of spruce cones. Striking genetic differences have been noted between the early breeding populations and populations that did not change their breeding season, suggesting an instance for genealogical phenotypic plasticity (Réale et al., 2003).

Evidence for phenological shifts should not be misinterpreted as rapid adaptations of species and their life history strategies in face of climate change. Although these corroborative facts indicate that certain species respond positively to changing climate, such response should not be assumed to be cosmopolitan, general patterns that occur in all the species across all the biomes (Parmesan, 2006). Most often, only a handful of temperate, arctic and subarctic species have adapted to climate change. Most tropical and subtropical species have not shown any adaptations or altered life history strategies in response to climate change (Harrington et al., 1999). The ecological niche of a given species can become highly influenced by climate, but there are numerous other factors that cumulatively determine a species survival, which strictly involve interactions with other species of the same ecosystem. Further, the overall ecological niche of all the species is the prime determinant of ecosystem function. Therefore, preserving species interactions and their realized niches are imperative to sustain intact functional integrity of an ecosystem. Nonetheless, component species of a given ecosystem reacts differentially to environmental cues, and so they do to the climate change. Inharmonious response of component species in symbiotic ecological associations to climate change will bewilder survival of component species. Similarly, unparalleled responses to climate change from different species of an ecosystem jeopardize its' sustainability and ecological integrity, ultimately terminating in ecological destabilization.

Climate change can potentially disrupt coordination in timing between the life cycles of two or more different taxa, such as predators and their prey, herbivorous insects and their host plants, parasitoids and their host insects, and animal pollinators and 
flowering plants, seed-bearing trees and dispersal agents (Visser \& Both, 2005). Inouye et al. (2000) reported asynchrony between timing of emergence from hibernation of Yellow-belied marmots and their sprouting of food pants. This observation was based on a 20-year study period at Rocky Mountain Biological Station in Colorado. Marmots arose from hibernation 23 days earlier than usual, purportedly due to a $1.4^{\circ} \mathrm{C}$ change in local temperature. On the contrary, emergence of the flowering plants and snow melting periods were unaffected by the temperature change. Consequently, marmots confronted a severe food deprivation in the spring, resulting unexpected spring mortality. Even surviving individuals suffered reduced reproductive success due to lack of energy for reproduction. More complex, climate affiliated phenomena resulting from trophic mismatches have also been documented. Phenological asynchrony has been reported in butterfly Euphydryas editha of Western United States. Unusually warm and dry years dissociated the relationship between emergence of butterflies relative to senescence times of their larval hosts and the time of blooming of adult nectarine plants. This scenario led to a dramatic population crash among this butterfly species (Singer \& Thomas, 1996). Such discrepancies are evident among migratory species where they become food-deprived after or during migration (Visser et al., 1998). Shorebirds such as sandpipers and plovers migrate from Central and South America to Arctic to breed. During this longdistance migration, they use Delaware Bay (Northeastern US seaboard) as a staging site, where they feed on horseshoe crabs emerging from the ocean to lay their eggs on beaches (Root, 1988). Foraging at Delaware Bay is essential to replenish their energy storage to continue migration. Once the birds arrive in arctic breeding grounds, both adults and their newly hatched chicks rely on Arctic insects. This highlights the importance of Arctic insects for both breeding success and juvenile survival of shorebirds (Root \& Schneider, 2002). For the purpose of migration to be successful, bird's advent at the staging site and migratory destination must coincide with crab spawning and insect blooming, respectively. Both events are highly temperature mediated. Warming climate triggered early spawning of crabs and insect blooming, where the arrival of shorebirds at the staging sites and breeding grounds did not coincide with optimum food availability. This critically reduced the birds' survival and reproductive success (Pearson \& Dawson, 2003). A similar dissociation of ecological integrity was observed in several populations of the
European Great Tit, whose reproductive success and juvenile survival is strictly dependant on maximum availability of caterpillars (especially those of the winter moth) after eggs hatch. The spring advancement and unusually warmer spring temperature advanced metamorphosis of caterpillars, but not all populations of great tits followed early advent of spring. As a result, hatchlings become food-deprived, and abided significant population decline (Bradshaw \& Holzapfel, 2006). In all these examples, it is evident that most often, species such as invertebrates that have a short life cycle and a short generation time will readily adapt to climate change and will reestablish their environmental relationships. But, long-lived species with a long generation time cannot adapt genetically in the rate that climate changes. In Great Britain, climate change induced early breeding in Triturus newts, but no change in the breeding phenology of the Ranid frog Rana temporaria (Beebee, 1995). Both of these species breed and forage in ephemeral ponds. The variation in responses to climate change has caused early maturation of newts that started to feed voraciously on frog eggs, embryos and larvae ensuing low abundance of ranids.

Climate change has a potential to alter the demographic structure of lower vertebrates, particularly reptiles, amphibians and certain fish. Unlike most other advanced vertebrates, sex determination of reptiles is dependent on incubation temperature of embryogenesis, not the zygotic genetics. Further, both oogenesis and spermatogenesis of reptiles are temperature driven. Therefore, certain temperature extremities will yield a bias in the sex ratio among reptiles. If chelonian eggs are incubated at high temperature, exclusively females will be produced where as low temperature will do the opposite (Bull, 1980). The painted turtle (Chrysemys picta) provides the ideal example for temperature dependent sex determination. The offspring sex ratio of this species is highly influenced by mean (summer) July temperature. Moderate summer temperature $\left(28-30^{\circ} \mathrm{C}\right)$ yields a balanced sex ratio. But, even a modest rise in change in temperature by $2-4^{\circ} \mathrm{C}$ will queer production of male offspring (Janzen, 1994). Among lizards, the complete opposite has being recorded (Adolph \& Porter, 1993). Crocodiles showed the most intrinsic temperature dependent sex determination where both temperature extremities produced females and intermediate temperature yielded males (Rhen \& Lang, 1998). Two different endocrine cascades, each requiring a 
particular enzyme for activation, determine the gonadal differentiation of vertebrates. Among reptiles, each enzyme is activated by distinct temperature regimes. Being poikilotherms, this becomes the physiological mechanism behind temperature dependent sex determination among reptiles (Janzen, 1994). Life cycle continuation of a particular species is partly determined by having an optimal sex ratio within its' population. The optimality of the sex ratio varies depending on the mating system of different species. For example, a species with lifetime monogamy requires a neutral sex ratio to achieve the best reproductive success, hence a male biased sex ratio in a monogamous species will bewilder the productive success of the entire population. Therefore, altered sex ratios among offspring will cause implications for their sexual reproduction of the future generations (Le Galliard et al., 2005).

\section{Emergence of wildlife diseases and pest infestations}

Deterioration of wildlife and pest attacks has been linked to climate change in numerous instances all over the globe. Causatives of wildlife diseases and pests that opportunistically seize climate change to their advantage are chiefly microscopic endoparasites and arthropod ectoparasites and disease vectors. Multiple factors can be highlighted that can potentially underlie surge of wildlife diseases and pests paralleling climate change. First, adverse climate conditions can induce physiological stress to the hosts, increasing their vulnerability and decreasing their immunity to pathogens and pests (Harvell et al., 1999). Secondly, unusually high or cold temperature can enhance the activeness of pests and pathogens (Dukes et al., 2009). Further, increasing temperature will increase distribution of vectors, helping them to expand their natural geographical limits (Harvell et al., 2002). Besides, thermal anomaly increases the rate of incubation, development, and reproduction of parasites inside vectors and favors the survival of vectors (Harvell et al., 2002). Similar trends are observed in maturation and propagation of pests (Rosenzweig et al., 2001). Higher reproductive success of pathogens and pests increases their density inside or on a single host, which further ensure their virulence and infectivity. Besides, pests and pathogens benefit from climate change indirectly, when adverse climate conditions deteriorate the immunity and health condition of hosts, making them highly susceptible for infections and pest attacks (Harvell et al., 2002). In Great Britain, recurrent seasonal pest infestations have become commonplace and sometimes duration of the infestation has protracted (Westgarth-Smith et al., 2007). In Europe, certain pests have expanded their geographical realm, and have expanded northward, presumably following the regions where the atmospheric temperature has risen. Therefore, pests that have previously infested tropical and subtropical biomes have now invaded temperate and polar regions (Battisti et al., 2005). Further, global warming helped some pests to extend their range to upper altitudes. Changing climate enhances spatial distribution of pests, particularly by bringing environmental conditions of a native habitat within a pest's thermal optima. Physiologically favorable environmental conditions will reduce generation time and mortality while increasing reproductive success, foraging efficiency, metabolism, egg production and juvenile survival (Lindgren \& Gustafson, 2001).

The Pine Processionary moth (Thaumetopoea pityocampa) provides an ideal example for range expansion of pests. This moth has expanded its range northward by $87 \mathrm{Km}$ in France. In Italy, they expanded their range into upper elevations by 110 $230 \mathrm{~m}$. The Pine Processionary moth capitalized on reduced nighttime temperatures and warmer winter temperatures, which nurtured the foraging efficiency and longevity of the insect, effectively allowing to exposited its' temporal niche (Battisti et al., 2005). Similarly, the Pine bark beetle of southern Alaska, British Columbia and parts of northwest United States benefited from longer and hotter summers, where they doubled their generation turnover rate, resulting in massive tree mortality due to devastating infestations (Berg et al., 2006; Taylor and Carroll, 2004). Most often, pest species are carriers of disease agents, such as fungi, bacteria, virus, and metazoan parasites. Thence, augmented range of a pest potentially can convoke pandemics (Sutherst, 1998). Unusually warm climate conditions as well as higher-thannormal wet conditions have enabled parasites to expand their distributions, infecting a larger proportion of their potential hosts. In Hawaiian Islands, warming climate has increased the susceptibility of Hawaiian Honeycreepers to avian malaria. Rising temperature in the Hawaiian Islands has broadened the distribution of anopheline mosquitoes, allowing them to move into higher altitudes, invading into the previously mosquito-free range occupied by the birds, and thereby increasing the range overlap between the birds and mosquitoes. Avian malaria has been responsible for local extirpation of Hawaiian honeycreepers from lowlands. Given to the evident range expansion of 
the vector-mosquitoes, survival of the remnant highland populations are highly questionable (Benning et al., 2002). Further, high temperature may alter the behavior of hosts allowing more contact between infected and susceptible hosts so that the efficiency of transmission among different host individuals could increase. For example, high temperature enhances duration of breeding seasons for some reptiles where increased number of copulations among mating pairs results close physical contacts, allowing parasites to spread easily among hosts (Leuteritz \& Hofmeyr, 2007). Moreover, high temperature and prolongation of warmer seasons heightens physical activities of hosts, particularly locomotion, including longdistance migration. On one hand, such behavioral alterations enhance the exposure of hosts to pathogens. On the other hand, parasites harbored by such hosts will be inadvertently introduced to different locations, allowing them to expand their geographical limits. High ambient temperature elevates metabolism. Hence, warm climate could increase the feeding rate of sanguivorous parasite vectors such as diptera flies, allowing fly-borne parasites to complete their lifecycles in quick successions, with a high probability of infecting larger number of hosts in a shorter time period (Dukes et al., 2009).

Chytrid is a key parasitic fungus that has successfully exploited global warming, resulting mass population declines among amphibians globally (Pounds et al., 1999). This fungus requires an optimum temperature of $23^{\circ} \mathrm{C}$ for its maximum virulence and will perish above $30^{\circ} \mathrm{C}$ and gets inactivated below $15^{\circ} \mathrm{C}$ (Piotrowski et al., 2004). In Costa Rica montane rainforests, increased nighttime temperature and decreased daytime temperature presented the ideal thermal optima for Chytrid, opening up pathways for it to become highly infectious (Harvell et al., 2009). Naturally, the lower elevation areas of these montane forests were too warm for the survival of chytird and higher elevation regimes were too cool for the fungus to remain infective. But, with increases sea surface temperature in Caribbean Sea, oceanic evaporation and water vapor holding capacity of the atmosphere increased materially (Pounds et al., 1999). Both of these conditions promoted orographic cloud formation. Thick cloud cover shaded the mountain habitats from solar heating in the daytime and prevented loss of heat form the mountains in the nighttime. Ultimately, the physiological thermal optima was provided for the fungus to achieve its' maximum virulence, which terminated in extinctions of several endemic amphibians with severe declines in other amphibian populations (Pounds et al., 2005; Harvell et al., 2009).

\section{Effects on extinction}

Climate change alters structure, resource availability and environmental favorability of habitats rendering them unsuitable for native fauna and flora, predisposing them to extinction (Omas, 2004). Reduced resource availability, mainly food, water, and breeding habitats lead to reduced reproductive success, decreased physical fitness and lower survivorship (Herman \& Scott, 1992; Thomas et al., 2003). Reasons behind climate change driven ecological catastrophes are increased evapotranspiration, increased moisture deficiency, frequent fluctuations in moisture availability, intensified natural disasters and perturbations (Dale $\&$ Rauscher, 1994). Climate change can be a crucial risk factor particularly for habitat specialists such as amphibians. Extinction of several amphibians of South and Central American rainforests has been attributed to decreased precipitation, increased dryness and low relative humidity. For example, in cloud forests of Costa Rica, Golden Toad (Bufo periglenes) has gone virtually extinct and Harlequin Frog (Atelopus variuns) has suffered local extinction where both events coincided with absence of the cold-borne mist with increased ambient temperature. Many amphibian populations are declining rapidly that corresponds with warming trends, mostly in tropical rainforests which are considered amphibian hotspots (Pounds et al., 1999; Parmesan, 2006).

Miles et al. (2004) projected the climate change scenario for year 2095 in Amazonia, a hydrological basin of the River Amazon and found out that 28 of 69 species can become nonviable. Their projection showed extremely low population densities with reduction in distribution range of those species so that they are highly susceptible extinction through external stochastic events and genetic drift. Climate change can drive extinction, locally, (where certain subpopulations can get wiped-out), and globally, (depending on the original distribution extent, adaptability and habitat selection of the concerned species). As explained earlier, climate change shrinks distribution range of certain species. Contracted geographical ranges always present strict limitations in essential resources and physical space while increase the probability of inbreeding depression. Further, extinction of subpopulations results lose of genetic diversity through bottlenecking, where certain genes that provide 
phenotypic plasticity to withstand extreme climates and epidemics will be omitted from the metapopulation (Peters \& Darling, 1985).

There have been opposing contentions regarding which biota is most susceptible to extinction upon climate change. Some argues that the most devastating impacts of climate change occur in high latitudes and high altitudes, primarily due to lack of alternative physical space to migrate if climate change render their original habitats unsuitable (Parmesan, 2006). Nonetheless, temperate and polar species have broad physiological tolerance regimes for different climate conditions, particularly for temperature. Given to natural seasonal variation, which could undergo extreme events, these species are well adapted morphologically, physiologically, biochemically, and behaviorally for a wide environmental variability throughout their evolutionary history (Anisimov et al., 2007). Additionally, they are well under their physiological and thermal optima. On the contrary, low latitude and equatorial species such as those occupying tropical ecosystems have a fairly narrow environmental and physiological tolerance range. High environmental and climatic stability in the tropics does not require having adaptations for changes in the climate (Deutsch et al., 2008). Besides, given to the natural consistency of climatic characteristics of tropics, these species are quite close to their thermal and physiological optima. Therefore, even a minute change in the climate can impose catastrophic consequences on low latitude and equatorial biota (Deutsch et al., 2008). Further, species in low-latitudes are the furthest from polar regions. Therefore, they will have to migrate greater distances, conquering many geographical barriers if climate changes. The distance and geography may serve as insurmountable constraints that prevent or belittle the migration of these species in search of their thermal associations. As a result, species occupying the southernmost range in the northern hemisphere are most susceptible for extinction (Lee \& Jetz, 2008). Therefore, climate driven extinction is non-random. The North American population of the Edith's checkerspot butterfly (Euphydryas editha) provides evidence for non-random extinction. On average, persisting subpopulations resided $2^{\circ}$ further north than regions resided by extinct subpopulations. The Mexican subpopulations were four-folds susceptible to extinction than the Canadian subpopulations (Hughes, 2000). The Edith's chekerspot butterfly showed a similar trend along elevation gradients in Mexico and Canada. According to a survey conducted during 1993-1996, the population residing 0-2400 m elevation regime have undergone $40 \%$ extinction, concerted with $14 \%$ reduction in snowpack and 7-day advancement in the melting date. On the contrary, the populations occupying $2400-3500 \mathrm{~m}$ altitude range only suffered $8 \%$ of population decline, where the snowpack has increased by $8 \%$ without a significant change in the melting dates. The changes in the snowpack thickness and melting dates were derived from data over 50 years (Parmesan, 2006).

The above evidence does not imply that Polar Regions are unhindered from climate change. Most biological activities of Polar Regions are strictly dependant on presence of land and sea ice (Hansen et al., 1996). Ice shelves in high latitudes function as the substrate for growth of primary producers and certain invertebrates that occupy lower trophic levels (Frasar, 1999). It is a well known fact that global warming induced rapid melting of polar ice cover, which initiates a bottom-up trophic cascade (Tynan \& DeMaster, 1997). The bottom-up trophic cascade brings noxious consequences to the top predators in food webs. In Antarctica, Adelie penguins (Pygoscelis adeliae) and emperor penguins (Aptenodytes forsteri) suffered massive declines since 1970 and consequently, the northernmost subpopulations of both species of Antarctica are fringing extinction (Gross, 2005; Barbraud \& Weimerskirch, 2001). Loss of ice shelves degraded habitats of these penguins. A similar scenario is evident in the terrestrial Arctic ecosystems, where the polar bears are declining both in abundance and mean body weight, which are concert with the loss of ice shelves, the foraging grounds of polar bears. Warming trends have jeopardized ringed seals, which serves as the major prey for polar bears (Ferguson et al., 2005). The Canadian Wildlife Service linked health deterioration of polar bears during the past two decades (since 1999) to rising spring temperatures in the Hudson Bay and the early break-up of sea ice in and around the Arctic Circle. Polar bear subpopulations have already declined in the Hudson Bay for this reason and are threatened in several others (COSEWIC, 2008). Several Arctic bird species who nest on ice sheets suffered population crash due to two facts accompanied by global warming. On one hand, declining ice cover limits space to build nests and on the other hand low ice cover reduces food abundance for hatchlings (Lovejoy, 2008). 


\section{Impacts at ecosystem and community levels}

Changes in climatic conditions, primarily precipitation and temperature will convoke alterations in ecosystems and communities, where certain ecosystems and communities can get completely replaced by another which is resilient to the newly induced ecological conditions (Sukumar et al., 1995). For instance, it has been noted that tropical and subtropical arid ecosystems being replaced by desert habitats, eliminating previously abundant, dominant species assemblages. This can be explained by the increased environmental severity deterring the original communities and aftermath colonization by xeric species (Sukumar et al., 1995). In most biogeographical regions, exotic species are favored by climate change. Climate change drives an increased physiological stress for the native biota, subduing the competitive abilities of native species. Most successful invasive species are native to hostile habitats with severe climates. Therefore they are well adapted through evolutionary processes to prosper in the face of climate change (Kelly \& Sullivan, 2010). Multiple species coexist under moderate climate conditions because all co-occurring species are equally favored by moderate climate conditions. But, under climate change, a single species in a highly diverse community will get physiologically benefited, outcompeting the rest. For example, British-native plant Oxlip coexists under high moisture regimes with Dog's Mercury but has been outcompeted under dry conditions in numerous occasions (Ford, 1982). Temperature and humidity are two key factors that govern many ecological conditions and can limit survival, growth, reproduction and dispersal of non-native species. Therefore, most often, exotic invasions under natural climate regimes are transient (Competitive exclusion of a worldwide invasive pest by a native. Quantifying competition between two phytophagous insects on two host plant species (Paini et al., 2008). But with warming climate, alien species introduced from warmer regions will readily establish with their initial colonization being prolonged. With sustained high air temperature, their reproduction and subsequent seed dispersion will be ensured (Twilley et al., 2001). It has been noted that exotic species establish numerically large and spatially extensive populations with warming climate, increasing their long-term persistency. For example, the Southern green stink bug Nezara viridula, formally a subtropical species expanded its range into temperate regions such as Europe and Japan since 1960s which coincides with increasing winter temperature which decreased the mortality of migrating individuals. This invasive insect has displaced a considerable number of native insects within their invaded range (Todd, 1989). In Florida, a bamboo-like Eucalyptus species successfully invaded Everglades wetlands with increasing atmospheric temperature. The exotic invasion increased drainage and frequency of fire events, both of which drastically changed the wetland characteristics of Everglades (Myers, 1983).

Further, with the stress exerted by climate change, the primary production of that ecosystem will dwindle. Low primary productivity will lead to low ecosystem productivity, which functions as a negative feedback cycle, rendering the entire ecosystem less resilient to climate change (Lu et al., 2009). Moreover, low productivity, increased environmental stress, exotic invasions and disruptions in ecosystem service culminate in reduced biodiversity and increased homozygosity in previously heterozygous ecosystems (Lindenmayer, 2009). Another community level issue of global warming is early senescence and forest diebacks due to physiological stress and habitat modification induced by changing climate and abnormal ambient temperature (Cox et al., 2004). Further, the resilience of ecosystems and communities, particularly vegetation communities to disturbances such as grazing, storms and forest fires have significantly declined with climate change as well (Nitschke et al., 2006).

\section{Conclusive remarks}

Climate change is globally evident and can affect biodiversity all over the world in varying extent. This could finally result loss of many species, primarily habitat specialists and those that are restricted to narrow geographical ranges. On the contrary, certain species are already showing phenological changes to accommodate oneself under global climate change. However, there is a strong bias on global climate change research. Majority of the studies conducted so far address phenological alterations, range shifts and future distribution of species in predicted climate change based on mathematical atmospheric models. The scope of climate change research targeting biodiversity should be broadened with inclusion of less-researched topic. For instances, more work needed to be done regarding effects climate change and global warming on disease ecology and dynamics in wildlife and natural habitats. Further, addressing responses of ecosystems, ecosystem functions, and communities in face of global warming is imperative. In addition, climate change 
should not be considered as a single risk factor on biodiversity conservation. Instead, climate change should be considered as one of the several horsemen that synergistically imperil global biodiversity, particularly, in conjunction with human disturbances, habitat loss and overexploitation. Applying novel technology such as GIS (Geographic Information Systems) and remote sensing should essentially be used in analyzing, interpreting and predicting effects of climate change on biodiversity. With the use of modern science and renovations of technology, solutions should be sought to minimize biodiversity loss in face of global climate change. Such preventive measures should be incorporated into national and global level biodiversity and wildlife conservation action plans.

\section{Literature Cited}

Abrahamson, D. E., 1989. Global Warming: The Issue, Impacts, Responses. In: Abrahamson, D. E. (Eds). The Challenge of Global Warming. Island Press, Washington DC: 33-43.

Adolph, S. C. and W. P. Porter, 1993. Temperature, Activity, and Lizard Life Histories. American Naturalist, 142: 273-295.

Ali, A. 1996. Vulnerability of Bangladesh to climate change and sea level rise through tropical cyclones and storm surges. Water, Air, \& Soil Pollution, 92:171179.

Allen, C. D. and D. D. Breshears, 1998. Droughtinduced shift of a forest-woodland ecotone: rapid landscape response to climate variation. Proceedings of National Academy of Science, 95: 14839-14842.

Alongi, D. 2008. Mangrove forests: Resilience, protection from tsunamis, and responses to global climate change. Estuarine, Coastal and Shelf Science, 76:1-13.

Anisimov, O. A., D. G. Vaughan, T. V. Callaghan, C. Furgal, H. Marchant, T. D. Prowse, H. Vilhjálmsson and J. E. Walsh, 2007. Polar Regions (Arctic and Antarctic). In: Parry, M. L., O. F. Canziani, J. P. Palutikof, P. J. van der Linden, C. E. Hanson (Eds.). Climate Change 2007: Impacts, Adaptation and Vulnerability. Contribution of Working Group II to the Fourth Assessment Report of the Intergovernmental Panel on Climate Change. Cambridge University Press. Cambridge: 653-685.

Appenzeller, T., 1992. What drives the climate. Discover, 58: 68-73.
Barbraud, C. and H. Weimerskirch, 2001. Emperor penguins and climate change. Nature, 411: 183-86.

Barnett, T. P., 1991. Greenhouse gas induced climatic change. Journal of geophysical researches, 91: 66596667.

Barry, J. P., C. H. Baxter, R. D. Sagarin and S. E. Gilman, 1995. Climate-Related, Long-Term Faunal Changes in a California Rocky Intertidal Community. Science, 267: 672-675.

Barry, R. G., 1998. Atmosphere, weather and Climate. Routledge, London: 409.

Battisti, A., M. Stastny, S. Netherer, C. Robinet, A. Schopf, A. Roques and S. Larsson, 2005. Expansion of geographic range in the pine processionary moth caused by increased winter temperatures. Ecological Application, 15: 2084-2096.

Beaumont, L. J. and L. Hughes, 2002. Potential changes in the distributions of latitudinally restricted butterfly species in response to climate change. Global Change Biology, 8: 954-971.

Beebee, T. J. C., 1995. Amphibian breeding and climate. Nature, 374: 219-220.

Beever, E. A., P. F. Brussard and J. Berger, 2003. Patterns of apparent extirpation among isolated populations of pikas (Ochotona princeps) in the Great Basin. Journal of Mammology, 84: 37-54.

Benning, T. L., D. LaPointe, C. T. Atkinson and P. M. Vitousek, 2002. Interactions of climate change with biological invasions and land use in the Hawaiian Islands: modeling the fate of endemic birds using a geographic information system. Proceedings of National Academy of Science, 99: 14246-14249.

Berg, E. E., J. D. Henry, C. L. Fastie, A. D. De Volder and S. M. Matsuoka, 2006. Spruce beetle outbreaks on the Kenai Peninsula, Alaska, and Kluane National Park and Reserve, Yukon Territory: Relationship to summer temperatures and regional differences in disturbance regimes. Forest Ecology and Management, 227: 219-232.

Berry, S. L. and M. L. Roderick, 2002. Estimating mixtures of leaf functional types using continentalscale satellite and climatic data. Global Ecology and Biogeography Letters, 11: 23-39. 
Berteaux, D., D. Reale, A. G. McAdam and S. Boutin, 2004. Keeping pace with fast climate change: Can Arctic life count on evolution? Integrative \& Comparative Biology, 44: 140-151.

Blenckner, T. and H. Hillebrand, 2002. North Atlantic Oscillation signatures in aquatic and terrestrial ecosystems: a meta-analysis. Global Change Biology, 8: 203-212.

Both, C., A. V. Artemyev, B. Blaauw, R. J. Cowie, A. J. Dekhuijzen, T. Eeva, A. Enemar, L. Gustafsson, E. V. Ivankina, A. Järvinen, N. B. Metcalfe, N. E. I. Nyholm, J. Potti, P. Ravussin, J. J. Sanz, B. Silverin, F. M. Slater, L. V. Sokolov, J. Török, W. Winkel, J. Wright, H. Zang, and M. E. Visser, 2004. Large-scale geographical variation confirms that climate change causes birds to lay earlier. Proceedings of Royal Society of London Series B, 271: 1657-62.

Bradshaw, W. E. and C. M. Holzapfel, 2006. Evolutionary response to rapid climate change. Science, 312: 1477-1478.

Brereton, R., S. Bennett and I. Mansergh, 1995. Enhanced greenhouse climate change and its potential effect on selected fauna of south-eastern Australia: A trend analysis. Biological Conservation, 72: 339-354.

Brewer, P. G. and M. Franklin, 2000. $\mathrm{CO}_{2}$ : the burning issue. Chemistry and Industry, 121: 567-571.

Bull, J. J., 1980. Sex Determination in Reptiles. The Quarterly Review of Biology, 55: 3-21.

Cayan, D. R., S. A. Kammerdiener, M. D. Dettinger, J. M. Caprio and D. H. Peterson, 2001. Changes in the onset of spring in the western United States. Bulletin of the American Meteorological Society, 82: 399-415.

Chavez, F. P., P. G. Stnitton, G. E. Friederich, R. A. Feely, G. C. Feldman, D. G. Foley and M. J. McPhaden, 1999. Biological and chemical response of the equatorial Pacific Ocean to the 1997-98 El Nino. Science, 286: 2126-2131.

Cosewic. 2008. COSEWIC Assessment and Update on Status Report on thte Polar Bear Ursus maritimus in Canada. Committee on the Status of Endangered Wildilfe in Canada, Ottawa, Canada

Cox, P. M., R. A. Betts, M. Collins, P. P. Harris, C. Huntingford and C. D. Jones, 2004. Amazon die-back under climate-carbon cycle projections for the $21 \mathrm{st}$ century. Theoretical and Applied Climatology, 78: 137-156.
Crick, H. Q. P., C. Dudley and D. E. Glue, 1997. Long-term trends towards earlier egg-laying by UK birds. Nature, 388: 526.

Dale, V. H. and H. M. Rauscher (1994). Assessing impacts of climate change on forests: the state of biological modeling. Climatic Change, 28: 65-90.

Dale, V. H., L. A. Joyce, S. McNulty, R. P. Neilson, M. P. Ayres, M. D. Flannigan, P. J. Hanson, L. C. Irland, A. E. Lugo, C. J. Peterson, D. Simberloff, F. J. Swanson, B. J. Stocks and B. M. Wotton, 2001. Climate Change and Forest Disturbances. Bio Science, 51: 723-734.

Deutsch, C. A., J. J. Tewksbury, R. B. Huey, K. S. Sheldon, C. K. Ghalambor, D. C. Haak and P. R. Martin, 2008. Impacts of climate warming on terrestrial ectotherms across latitude. Proceedings of National Academy of Science, 105: 6668-6672.

Dukes, J. S., J. Pontius, D. Orwig, J. R. Garnas, V. L. Rodgers, N. Brazee, B. Cooke, K. A. Theoharides, E. E. Stange, R. Harrington, J. Ehernfeld, J. Gurevitch, K. Lerdau, J. Stinson, R. Wick and M. Ayres, 2009. Response of insect pests, pathogens, and invasive plants species to climate change in the forests if northeastern North America: What can we predict?. Canadian Journal in Forest Research, 39: 231-248.

Dullinger, S., T. Dirnböck and G. Grabherr, 2004. Modelling climate change-driven treeline shifts: relative effects of temperature increase, dispersal and invisibility. Journal of Ecology, 92: 241-252.

Ellison, J. 2003. How South Pacific mangroves may respond to predicted climate change and sea-level rise. Climate Change in the South Pacific: Impacts and Responses in Australia, New Zealand, and Small Island States: 289-300.

Emanuel, K. L., 1985. Vegetation response to global warming. International Journal of Climatology, 4: 132-138.

Emmanuel, W. R., 1985. Climate change and the broad scale distribution of terrestrial ecosystem complexes. Climate Change, 7: 29-43.

Ericson, J. P., C. Vörösmarty, S. L. Dingman, L. G. Ward and M. Meybeck. 2006. Effective sea-level rise and deltas: causes of change and human dimension implications. Global and Planetary Change, 50: 63-82. 
Ferguson, S.H., I. Stirling and P. Mcloughlin, 2005. Climate change and ringed seal (Phoca hispida) recruitment in western Hudson Bay. Marine Mammal Science, 21: 121-135.

Field, C. D. 1995. Impact of expected climate change on mangroves. Hydrobiologia, 295:75-81.

Ford, M. J., 1982. The Changing Climate. George Allen and Unwin, London, UK: 199.

Forister, M. L. and A. M. Shapiro, 2003. Climatic trends and advancing spring flight of butterflies in lowland California. Global Change Biology, 9: 11301135 .

Frasar, I. H., 1999. Polar wildlife facing threat. Nature, 416: 325-328.

Gese, EM and S. Grothe, 1995. Analysis of Coyote predation on deer and elk during winter in Yellowstone National Park, Wyoming. American Midland Naturalist, 133: 36-43.

Gibbs, J. P. and A. R. Breisch, 2001. Climate warming and calling phenology of frogs near Ithaca, New York, 1900-1999. Conservation Biology, 15: 1175-1178.

Gordo O., L. Brotons, X. Ferrer and P. Comas, 2005. Do changes in climate patterns in wintering areas affect the timing of the spring arrival of trans-Saharan migrant birds?. Global Change Biology, 11: 12-21.

Grabherr, G., M. Gottfried and H. Pauli, 1994. Climate effects on mountain plants. Nature, 369: 448.

Gross, L., 2005. As the Antarctic ice pack recedes, a fragile ecosystem hangs in the balance. PLoS Biology. 3: e127.

Hannah, L., G. F. Midgley, T. Lovejoy, W. J. Bond, M. Bush, J. C. Lovett, D. Scott and F. I. Woodward, 2002. Conservation of Biodiversity in a Changing Climate. Conservation Biology, 16: 264-268.

Hansen, B., S. Christiansen, and G. Pedersen, 1996. Plankton dynamics in the marginal ice zone of the central Barents Sea during spring: carbon flow and structure of the grazer food chain. Polar Biology, 16: 115-128.

Harrington R., I. Woiwod and T. Sparks, 1999. Climate change and trophic interactions. Trends in Ecology and Evolution 14: 146-150.
Harvell, C. D., C. E. Mitchell, J. R. Ward, S. Altizer, A. P. Dobson, R. S. Ostfeld and M. D. Samuel, 2002. Climate warming and disease risks for terrestrial and marine biota. Science, 296: 2158-2162.

Harvell, C. D., K. Kim, J. M. Burkholder, R. P. Colwell, P. R. Epstein, D.J. Grimes, E. E. Hofmann, E. K. Lipp, A. D. Osterhaus, R. M. Overstreet, J. W. Porter, G. W. Smith and G. R. Vasta, 1999. Emerging marine diseases - climate links and anthropogenic factors. Science, 285: 1505-1510.

Harvell, C. D., S. Altizer, I. M. Cattadori, L. Harrington and E. Weil, 2009. Climate change and wildlife diseases: When does the host matter the most? Ecology, 90: 912-920.

Herman T. B. and F. W. Scott, 1992. Threat faced by vertebrates upon global warming. Climate Change, 12: 88-95.

Hersteinsson, P. and D. W. MacDonald, 1992. Interspecific competition and the geographical distribution of red and arctic foxes Vulpes vulpes and Alopex lagopus. Oikos, 64: 505-515.

Hickling, R., D. B. Roy, J. K. Hill and C. D. Thomas, 2005. A northward shift of range margins in British Odonata. Global Change Biology, 11: 502-506.

Hilbert, D. W. and B. Ostendorf, 2001. The utility of empirical, artificial neural network approaches for modelling the distribution of regional to global vegetation in past, present and future climates. Ecological Modelling, 146: 311-327.

Hilbert, D. W., B. Ostendorf and M. Hopkins, 2001. Sensitivity of tropical forests to climate change in the humid tropics of North Queensland. Austral Ecology, 26: $590-603$.

Hilbert, D. W., M. Bradford, T. Parker and D. A. Westcott, 2004. Golden bowerbird (Prionodura newtonia) habitat in past, present and future climates: predicted extinction of a vertebrate in tropical highlands due to global warming. Biological Conservation, 116: 367-377.

Hill, G. E., R. R. Sargent and M. B. Sargent, 1998. Recent change in the winter distribution of Rufous Hummingbirds. Auk, 115: 240-245.

Hill, J. K., C. D. Thomas and O. T. Lewis, 1999. Flight morphology in fragmented populations of a rare British butterfly, Hesperia comma. Biological Conservation, 87: 277-284. 
Hoffman, A. A. and P. A. Parsons, 1997. Extreme Environmental Change and Evolution. Cambridge University Press, Cambridge: 466.

Houghton, I. T., 2001. The science of climate change. Cambridge University Press, New York: 892.

Howell, S. N. G., 2002. Hummingbirds of North America: the photographic guide. Academic Press, San Diego, 219.

Hughes L., 2003. Climate change and Australia: trends, projections and impacts. Austral Ecology, 28: 423-443.

Hughes, L., 2000. Biological consequences of global warming: is the signal already. Trends in ecology and Evolution, 15: 56-61.

Inouye, D. W., B. Barr, K. B. Armitage and B. D. Inouye, 2000. Climate change is affecting altitudinal migrants and hibernating species. Proceedings of the National Academy of Science of the United States of America 97: 1630-1633.

IPCC, 1992. Climate change - the supplementary report to the IPCC impacts assessment. Australian Government Publishing Service, Canberra: 122.

IPCC, 2001. Climate change: impacts, adaptations and vulnerability. Cambridge University press, Cambridge: 1032.

IPCC, 2007a. Climate Change 2007: The Physical Science Basis. Cambridge University Press, Cambridge, United Kingdom and New York, 996.

IPCC, 2007b. Climate Change 2007: Impacts, Adaptation and Vulnerability. Cambridge University Press, Cambridge, 976.

Janzen, J. J., 1994. Population biology, climate change and temperature-dependent sex determination in reptiles. Proceedings of National Academy of Science, 91: 7487-7490.

Jordano D., E. C. Retamosa and H. Fernandez, 1991. Factors facilitating the continued presence of Colotis evagore (Klug 1829) in southern Spain. Journal of Biogeography, 18: 637-646.

Kelly, D. and J. J. Sullivan, 2010. Life histories, dispersal, invasions, and global change: progress and prospects in New Zealand ecology, 1989-2029. New Zealand Journal of Ecology, 34: 207-217.
Kirschbaum, M. U. F. and W. Cen, 1999. A forest growth model with linked carbon, energy, nutrient and water cycles. Ecological Modelling, 118: 17-59.

Knapp, A. K., C. Beier, D. D. B. Aimée T. Classen, Y. Luo, M. Reichstein, M. D. Smith, S. D. Smith, J. E. Bell, P. A. Fay, J. L. Heisler, S. W. Leavitt, R. Sherry, B. Smith and E. Weng, 2008. Consequences of more extreme precipitation regimes for terrestrial ecosystems. BioScience, 58: 811-821.

Le Galliard, J. F., P. S. Fitze, R. Ferriere and J. Clobert, 2005. Sex ratio bias, male aggression, and population collapse in lizards. Proceedings of National Academy of Science USA, 102: 18231-18236.

Lee, T. M. and W. Jetz, 2008. Future battlegrounds for conservation under global change. Proceeding of the Royal Society B: Biological Sciences, 275: 1261-1270.

Leuteritz, T. E. J. and M. D. Hofmeyr, 2007. The extended reproductive season of tent tortoises (Psammobates tentorius tentorius): A response to an arid and unpredictable environment. Journal of Arid Environments, 68: 546-563.

Lindenmayer, D. B., 2009. Forest wildlife management and conservation. Year in Ecology and Conservation Biology, 1162: 284-310.

Lindgren, E. and R. Gustafson, 2001. Tick-borne encephalitis in Sweden and climate change. Lancet 358: $16-18$

Lovejoy, T., 2008. Climate change and biodiversity. Revue scientifique et technique, 27: 331-338.

Lu, Y., Q. Zhuang, G. Zhou, A. Sirin, J. Melillo and D. Kicklighter, 2009. Possible decline of the carbon sink in the Mongolian Plateau during the 21st century. Environmental Research Letters, 4: 1-8.

MacInnes, C. D., E. H. Dunn, D. H. Rusch, F. Cooke and F. G. Cooch, 1990. Advancement of goose nesting dates in the Hudson Bay region, 1951-1986. The Canadian Field-Naturalist, 104: 295-297.

McGuire, A. D., Melillo, J. M., Kicklighter, D. W., Moore, B., Vorosmarty, C. J. and A. L. Schloss, 1993. Global climate change and terrestrial net primary production. Nature, 363: 234-240.

Menzel, A., T. H. Sparks and D. B. Roy, 2006. Altered geographic and temporal variability in phenology in response to climate change. Global Ecology and Biogeography, 15: 498-504. 
Miles, L., A. Grainger and O. L. Phillips, 2004. The impact of global climate change on tropical forest biodiversity in Amazonia. Global Ecology and Biogeography, 13: 553-565.

Myers, R. L., 1983. Site susceptibility to invasion by the exotic tree Melaleuca quinquenervia in southern Florida. Journal of Applied Ecology, 20: 645-658.

Neelin J. D., C. Chou and H. Su, 2003. Tropical drought regions in global warming and El Nin o teleconnections. Geophysics Research Letters, 30: 2275, doi:10.1029/2003GL018625.

Nitschke, C. R., 2006. Integrating climate change into forest planning: A spatial and temporal analysis of landscape vulnerability. $P h D$ dissertation, University of British Columbia, Vancouver.

Omas, C. P., 2004. Extinction risk from climate change. Nature, 421: 145-148.

Ott, J., 2001. Expansion of Mediterranean Odonata in Germany and Europe - Consequences of climate changes. In: Walther, G., Burga, C. A., Edwards, P. J. (Eds.). "Fingerprints" of climate change: adapted behaviour and shifting species ranges. Kulwer Academic \& Plenum Publishers. New York, 89-112.

Ozerda, J. H. and N. Boreal, 1990. Shifts of vegetation belts as response to Climate change. Global planet, 8: 149-159.

Paini, D. R., J. E. Funderburk and S. R. Reitz, 2008. Competitive exclusion of a worldwide invasive pest by a native. Quantifying competition between two phytophagous insects on two host plant species. Journal of Animal Ecology, 77: 184-190.

Parmesan, C., 2006. Ecological and evolutionary responses to recent climate change. Annual Review of Ecology, Evolution and Systematics, 37: 637-669.

Parmesan, C. and G. Yohe, 2003. A globally coherent fingerprint of climate change impacts across natural systems. Nature, 421:37-42.

Parmesan, C., N. Ryrholm, C. Stefanescu, J. K. Hill, C. D. Thomas, H. Descimon, B. Huntley, L. Kaila, J Kullberg, T Tammaru, W. J. Tennent, J. A. Thomas and M. Warren, 1999. Poleward shifts in geographical ranges of butterfly species associated with regional warming. Nature, 399: 579-83.
Parmesan, C., T. L. Root and M. Willig, 2000. Impacts of extreme weather and climate on terrestrial biota. Bulletin of the American Meteorological Society, 81: 443-450.

Pearson, R. G. and T. P. Dawson, 2003. Predicting the impacts of climate change on the distribution of species: are bioclimate envelope models useful? Global Ecology \& Biogeography, 12: 361-371.

Pernetta, J. C. 1992. Impacts of climate change and sea-level rise on small island states: National and international responses. Global Environmental Change, 2:19-31.

Pernetta, J. 1993. Mangrove forests, climate change and sea level rise: hydrological influences on community structure and survival, with examples from the Indo-West Pacific. IUCN.

Peters, I., 1998. Alterations in forests ecosystems in response to climate. Climate Change, 36: 1253-1240.

Peters, R. L. and D. S. J. Darling, 1985. The greenhouse effect and nature reserves. BioScience, 35: 707-717.

Piotrowski J. S., S. L. Annis and J. E. Longcore, 2004. Physiology of Batrachochytrium dendrobatidis a chytrid pathogen of amphibians. Mycologia, 96: 9-15.

Pounds, J. A., M. P. L. Fogden and J. H. Campbell, 1999. Biological response to climate change on a tropical mountain. Nature, 398: 611-15.

Pounds, J. A., M. P. L. Fogden and K. L. Masters, 2005. Responses of natural communities to climate change in a highland tropical forest. In: Lovejoy, T., Hannah, L. (Eds.). Climate Change and Biodiversity. Yale University Press, New Haven, 70-74.

Réale D, A. G. McAdam, S. Boutin and D. Berteaux, 2003. Genetic and plastic responses of a northern mammal to climate change. Proceedings of the Royal Society of London. Series B, Biological Sciences, 270: 591-596.

Rhen, T. and J. W. Lang, 1998. Among-family variation for environmental sex determination in reptiles. Evolution, 52: 1514-1520.

Root, T. L., 1988. Energy constraints on avian distributions and abundances. Ecology, 69: 330-339. 
Root, T. L. and S. H. Schneider, 2002. Climate change: Overview and implications for wildlife. In: Schneider, S. H. and T. L. Root (Eds.). Wildlife Responses to Climate Change: North American Case Studies. Island Press, Washington DC: 1-56.

Rosenzweig, C., A. Iglesias, X. B. Yang, P. R. Epstein and E. Chivian, 2001. Climate change and extreme weather events: implications for food production, plant diseases, and pests. Global Change Human Health, 2: 90-104.

Singer M. C. and Thomas C. D., 1996. Evolutionary responses of a butterfly metapopulation to human and climate-caused environmental variation. American Naturalist, 148: 9-39.

Still, C. J., P. N. Foster and S. H. Schneider, 1999. Simulating the effects of climate change on tropical montane cloud forests. Nature, 398: 608-610.

Sukumar, R., H. S. Suresh and R. Ramesh, 1995. Climate change and its impact on tropical montane ecosystems in southern India. Journal of Biogeography, 22: 533-536.

Sutherst, R. W., 1998. Implications of global change and climate variability for vector-borne diseases: generic approaches to impact assessments. International Journal for Parasitology, 28: 935-945.

Taylor, S. W. and A. L. Carroll. 2004. Disturbance, forest age, and mountain pine beetle outbreak dynamics in BC: a historical perspective. In T. L. Shore, J. E. Brooks and J. E. Stone (eds.), Mountain Pine Beetle Symposium: Challenges and Solutions. Natural Resources Canada Information Report BC-X399, Kelowna, British Columbia: 41-51.

Thomas, C. D. A. Cameron and R. E. Green, 2003. Extinction risk from climate change. Nature, 427: 145147.

Thomas, C. D. and J. J. Lennon, 1999. Birds extend their ranges northwards. Nature, 399: 213

Titus, J. G., 1988. Greenhouse effect, sea level rise and coastal wetlands. EPA Office of Policy, Planning, and Evaluation, Washington, DC.

Todd, J. W., 1989. Ecology and behavior of Nezara viridula. Annual Reviwes of Entomology, 34: 273 -292.

Twilley, R. R., E. J. Barron, H. L. Gholz, M. A. Harwell, R. L. Miller, D. J. Reed, J. B. Rose, E. H. Siemann, R. G. Wetzel and R. J. Zimmerman, 2001.
Confronting climate hange in the Gulf Coast Region: Prospects for sustaining our ecological heritage. Union of Concerned Scientists, Cambridge, Massachusetts, and Ecological Society of America, Washington, DC.

Tynan, C. T. and D. P. DeMaster, 1997. Observations and predictions of Arctic climatic change: potential effects on marine mammals. Arctic, 50: 308-322.

Ulrich, R., 1990. Forest decline in West Germany. Environmental Science and Technology, 24: 436-441.

Valiela, I. and J. L. Bowen, 2003. Shift in winter distribution in birds: effects of global warming. Ambio, 32: 476-480.

Visser, M. E and C. Both, 2005. Shifts in phenology due to global climate change: the need for a yardstick. Proceedings of Royal Society B, 272: 2561-2569.

Visser, M. E., van Noordwijk, A. J., Tinbergen, J. M. and C. M. Lessells, 1998. Warmer springs lead to mistimed reproduction in great tits (Parus major). Proceedings of Royal Society of London B, 265: 18671870.

Walther, G. R., E. Post, P. Convey, A. Menzel, C. Parmesan, T. J. C. Beebee, J. Fromentin, O. HoeghGuldberg and F. Bairlein, 2002. Ecological responses to recent climate change. Nature, 416: 389-395.

Warren, M. S., J. K. Hill, J. A. Thomas, J. Asher, R. Fox, B. Huntley, D. B. Roy, M. G. Telfer, S. Jeffcoate, P. Harding, G. Jeffcoate, S. G. Willis, J. N. GreatorexDavies, D. Moss and C. D. Thomas, 2001. Rapid responses of British butterflies to opposing forces of climate and habitat change. Nature, 414: 65-69.

Westgarth-Smith, A. R., S. A. G. Leroy, P. E. F. Collins and R. Harrington, 2007. Temporal variations in English populations of a forest insect-pest, the green spruce aphid (Elatobium abietinum), associated with the North Atlantic Oscillation and global warming. Quaternary International, 173-174: 153-160.

Wilson, J. W., D. Guti'errez, R. Agudo, V. J. Monserrat, 2005. Changes to the elevational limits and extent of species ranges associated with climate change. Ecology Letters, 8: 1138-46.

Woodward, F. I. and L. Rochefort, 1991. Sensitivity analysis of vegetation diversity to environmental change. Global Ecology and Biogeography Letters, 1: 7-23. 